Indonesian Journal of Biotechnology, June, 2015

Vol. 20 No. 1, pp.54-61

\title{
High Resolution Microsatellite Marker Analysis of Some Rice Landraces Using Metaphor Agarose Gel Electrophoresis
}

\author{
Kristamtini $^{1)^{*}}$, Taryono ${ }^{2}$ ), Panjisakti Basunanda ${ }^{2}$ ) dan \\ Rudi Hari Murti²)
}

1) Assesment Institute of Agriculture Technology, Yogyakarta, Indonesia
2)Faculty of Agriculture, Universitas Gadjah Mada, Yogyakarta, Indonesia

\begin{abstract}
Microsatellite markers or simple sequences repeats are DNA - based molecular techniques that are used to see the different among accessions and inbred lines. There are three methods to analysis the results of the polymerase chain reaction of microsatellite markers namely polyacrylamide gel electrophoresis (PAGE), capillary electroforesis, and Metaphor Agarose Gel Electroforesis (MAGE), and the Use of MAGE assessed more easily and economically the polymorphic pattern of DNA markers. This study aimed to obtain fast, effective and efficient in term of easy and cheap technique to identify microsatellite markers of some black rice cultivars and $\mathrm{F}_{2}$ populations from crosses between black with white rice. The results showed that MAGE successfully separated clearly SSRs alleles with different sizes of less than $25 \mathrm{bp}$.
\end{abstract}

Keywords: microsatellite markers, Metaphor Agarose Gel Electrophoresis (MAGE), and rice cultivar .

\section{Introduction}

Black rice became popular and began to be consumed as a functional food naturally or through certain processes, contained one or more compounds that were considered to have beneficial physiological functions to health. One of compounds present in black rice was anthocyanin (Yawadio et al., 2007). Black rice has potential as a viable source of antioxidants.

There was color diversity of black rice from dark purple to light purple. Therefore the identification of superiority was required so that it could be used as breeding material. Pabendon et al. (2003) suggested that knowledge about germplasm diversity and kindship among breeding materials were very important to plan crosses to produce hybrid lines. Lines that were made from genetically diverse sources could

*Corresponding author:

Kristamtini

Assesment Institute of Agriculture Technology, Yogyakarta, Email: krisniur@yahoo.co.id produce better hybrids compared with close kindship.

The evaluation of genetic diversity can be done with morphological, biochemical and molecular markers (Solouki et al., 2008). The use of molecular markers as a genetic marker is a tool which is able to look at genetic differences between inbred lines. Molecular markers hold two important roles in plant breeding programs, namely as a determinant of fingerprint and marker in the selection link with certain desirable phenotypic characteristics (McCouch and Tanksley, 1991). Pabendon et al., (2011) said that the marker technology can be used to answer questions related to genetic diversity, classification, and phylogeny related to germplasm management and tool of breeding and selection through gene markers. Several technologies based on DNA marker that are used widely were RFLP (Restriction Fragment Length Polymorphism), AFLP (Amplified Fragment Length Polymorphism), SSR (Simple Sequence repeats), and SNP (single nucleotide polymorphism) (Asif et al., 2008). 
Among numbers of molecular markers available, microsatellites or Simple Sequence Repeats (SSRs) have become frequent used marker system. Microsatellite markers consisted of 1-6 base pairs motif of DNA structure, repeated five times or more in a row sequentially (Vigouroux et al., 2002). Such markers spread and covered the whole genome, especially in eukaryotic organisms. This marker has been used in various studies, including genetic diversity for the identification of plant variety, and selection process of plant breeding material as called of Marker Assisted Selection (MAS). According to Azrai (2005), selection with DNA markers based on genetic traits were stable and not affected the environment.

Thesimplicity ofSSRs in theamplification and detection of DNA fragments, and high levels of generated polymorphism making this method was an ideal to be used in large sample numbers. SSR could be harvested using PCR (Polymerase Chain Reaction) technique. PCR used only small amounts of DNA with a small DNA segment amplification, approximately 100-300 bp (base pairs) of the genome. Moreover, SSRs could be applied without damaging the plant material because only a few was used in DNA extraction or may use other parts such as seeds or pollen (Senior et al., 1996). SSR technology was widely used because it was relatively practice, accurate, and produced high level of polymorphism, and even allowed the observation of multiple markers simultaneously (multiplex), and spread evenly throughout the genome (Susanto et al., 2009).

Another advantage of using microsatellite was codominant nature, meaning that it could distinguish between homozygous and heterozygous (Powell et al.,1996). Several considerations of using microsatellite in genetic studies included (1) SSR markers were abundant and evenly dispersed in the genome, diversity was very high (many alleles within loci), codominant and location of the genome could be known; (2) reproducibility and accuracy were very high; (3) these markers were very accurate for distinguishing the genotype, seed purity evaluation, mapping, and genotyping of selection for the desired characteristic; and population genetic studies and analysis of genetic diversity. Microsatellite markers has been widely used to identify the genetic diversity of several kinds of plant germplasm, such as Sorghum (Bucheyeki et al., 2009), maize (Pabendon et al., 2007), red local rice (Utami et al., 2009) and wheat (Zhang et al., 2005).

At the moment there were three methods of electrophoresis to analyze the results of the amplification using PCR of SSR, namely the Polyacrylamide Gel Electrophoresis (PAGE), capillary electrophoresis and Metaphor Agarose Gel Electrophoresis (MAGE). PAGE was the most common method and very useful (Cregan and Quigley, 1997). Amplification products in a polyacrylamide gel was usually visualized with radioactive, and fluorescent labels, and even silver staining. However, this technique required visualization of a radioactive activity which was quite expensive and dangerous, and required a longer exposure time. Capillary electrophoresis was used to determine the length of polymorphism microsatellite markers (Marino et al., 1995), but this method required highly sophisticated instruments and expensive labeled primer.

Metaphor Agarose Gel Electrophoresis (MAGE) was another approach to separate alleles of microsatellite markers (Abdurakhmonov et al., 2007). Metaphor agarose delivered twice resolution capability of a product best agarose, metaphor agarose provided clear and good resolution up to 20800 bp DNA fragments with $2 \%$ concentration, approached the polyacrylamide gel resolution.

Based on these conditions, this research was conducted to find a method that was faster, more effective and efficient due to easy use and cheap in price with high-resolution to identify genotypes using microsatellite in some black rice landraces. 
Materials and Methods

\section{Plants Materials and DNA Isolation}

Eleven landraces of black rice and 2 commercial white cultivars (Table 1) and 30 individual numbers of plant populations of $\mathrm{F}_{2}$ generation from crosses of black rice of Magelang hairless (S) and Situbagendit white rice $(G)$ were used in this study. DNA rice genome was isolated from plants materials using CTAB (Cetyl-trymethyl ammonium bromide) method (Doyle and Doyle, 1990).

Table 1. Eleven black rice landraces and 2 commercial white cultivars

\begin{tabular}{lc}
\hline Black rice landraces & Population \\
\hline 1. Melik & Black rice \\
2. Jlitheng & Black rice \\
3. Cempo Ireng & Black rice \\
4. Pari Ireng & Black rice \\
5. Black rice of NTT & Black rice \\
6. Blaack rice of Magelang (hairy) & Black rice \\
7. Black rice of Bantul & Black rice \\
8. Black rice of Magelang (hairless) & Black rice \\
9. Black rice of Sragen & Black rice \\
10. Black rice of Wonosobo & Black rice \\
11. Black rice of Banjarnegara & Black rice \\
12. Situbagendit & White rice \\
13. Inpari 6 & White rice \\
\hline
\end{tabular}

Young leaves of approximately $0.05 \mathrm{~g}$ which taken from the nursery were crushed by adding $800 \mathrm{~mL}$ CTAB preheated buffer $(65$ ${ }^{\circ} \mathrm{C}$ ) and poured in the micro tube. Tubes were incubated for $60 \mathrm{~min}$ at $65^{\circ} \mathrm{C}$ with inverted every 10 minutes. A 24 : 1 chloroform isoamyl alcohol solution (CIAA) of $400 \mathrm{~mL}$ was added to the tube. The tube was vortexed, and then centrifuged at $12.000 \mathrm{rpm}$ for 15 minutes. The supernatant was taken out and put into a new micro tube. Three $M$ sodium acetate was poured into the tube as much as $1 / 10$ volume of the supernatant. After the addition of cold isopropanol as much as $2 / 3$ the total volume (supernatant + sodium acetate), the tube was inverted properly and stored in the freezer for 24 hours. Furthermore, the tube was centrifuged at $12.000 \mathrm{rpm}$ for 10 minutes. The supernatant was taken and added 500 $\mathrm{mL}$ of $70 \%$ ethanol and the tube was inverted.
Furthermore, the tube was centrifuged at $12.000 \mathrm{rpm}$ for 5 minutes. The supernatant was discarded and the sediment was dried. Once dried, DNA was dissolved with $50 \mathrm{~mL}$ sterile aquabidest, then the DNA was ready to be quantified.

\section{PCR for Microsatellite Amplification}

In order to amplify the microsatellite sequence in the genome, PCR technique was used. RM-224 primer with forward: ATCGATCGATCTTCACGAGG; reverse base sequences: TGCTATAAAAGGCATTCGGG was chosen to amplify related microsatellite from total DNA genome of 11 black rice landraces, 2 commercial white rice cultivars and 30 individual plants of $\mathrm{F}_{2}$ populations from crosses of black rice (Magelang hairless) with Situbangendit white rice cultivar. PCR amplification was performed in a total volume of $10 \mu \mathrm{l}$ consisted of $5 \mu \mathrm{l}$ Go Taq Green PCR mix; $2 \mu$ l nuclease Freewater; $0.25 \mu$ l forward and reverse primers respectively, and $5 \mu \mathrm{l}$ total DNA genomes. The PCR program was set up for 5 minutes denaturation starters at a temperature of $94^{\circ} \mathrm{C}$, followed by 35 cycles consisted of: 1 minute denaturation at $94^{\circ} \mathrm{C}$, 1 minute annealing process at a temperature of $55^{\circ} \mathrm{C}, 2$ minutes elongation of the primer at $72^{\circ} \mathrm{C}$, the repetition of 2 steps through 4 steps as many as 13 times with touchdown program with a difference temperature of $0.5^{\circ} \mathrm{C}$ each cycle and lasted by primer extention at $72^{\circ} \mathrm{C}$ for $7 \mathrm{~min}$, and incubation phase at $4^{\circ} \mathrm{C}$.

\section{Gel Electrophoresis}

PCR product was analyzed using standard and MetaPhor ${ }^{\mathrm{TM}}$ (Lonza) agarose, with different concentrations, i.e. 1 and $2 \%$ standard agarose, and 2\% metaphor agarose. Each agarose types with different concentrations was dissolved in $1 x$ TBE (Tris-borate-EDTA) buffer separately by heating slowly. After all ingredients were dissolved, $0.01 \%$ DNA dye was added. Dissolved agarose was solidified by pouring into a gel tray, stored at $4{ }^{\circ} \mathrm{C}$ for $30-60$ 
minutes before use to obtain matrix gel with better resolution. After gel was ready, gel was assembled to electrophoresis tank and soaked with $1 \times$ TBE buffer. PCR results were loaded into the wells and electrophoresed for about 60 minutes at the voltage 80 volts and 400 Amphere. After electrophoresis, SSR products were visualized under UV Transilluminator and photographed.

\section{Result and Discussion}

Microsatellite showed high polymorphic, multi-allelic, and abundant in the genome (Kuleung et al., 2006), dispersed throughout the genome (Ijaz and Khan, 2009), and analyzed as DNA fragment in the size of 100 - 350 bp (base pair) (Kelestanie et al., 2013). Microsatellites are usually analyzed on standard agarose or poly-acrylamide gel electrophoresis (Wang et al., 2009). The agarose gel required simple devices, although it did not fit to the DNA segment size of
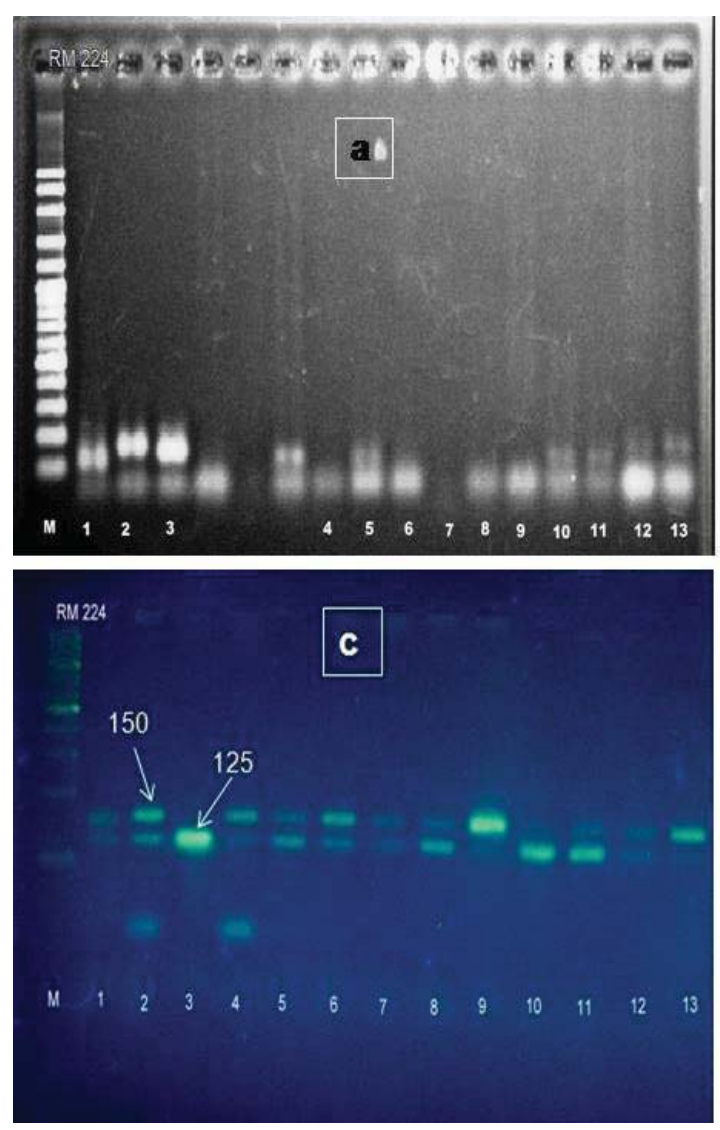

microsatellite and the result was normally not optimal. In case of poly-acrylamide gel electrophoresis, it was laboratory expensive. An easier, quicker and more reproducible method for electrophoresis and operation would be superior if enough resolution and sensitivity could be achieved. Metaphor system was indeed capable of tracking allelic inheritance (White and Kusunawa, 1997).

Metaphor agarose provided an acceptable resolution separation of $20-800$ bp fragments that would be fitted to the size of microsatellite given by poly-acrylamide gel resolution, whereas the theoretical resolution capacity was averaged $3.3 \mathrm{bp}$ within the size range of 160 - 307 bps (White and Kusunawa, 1997). Metaphor agarose gel electrophoresis was probably one of easy and economic method to separate allele of microsatellites (Asif et al., 2005).

Figure 1c showed the separation of the two alleles of RM 224 microsatellite markers

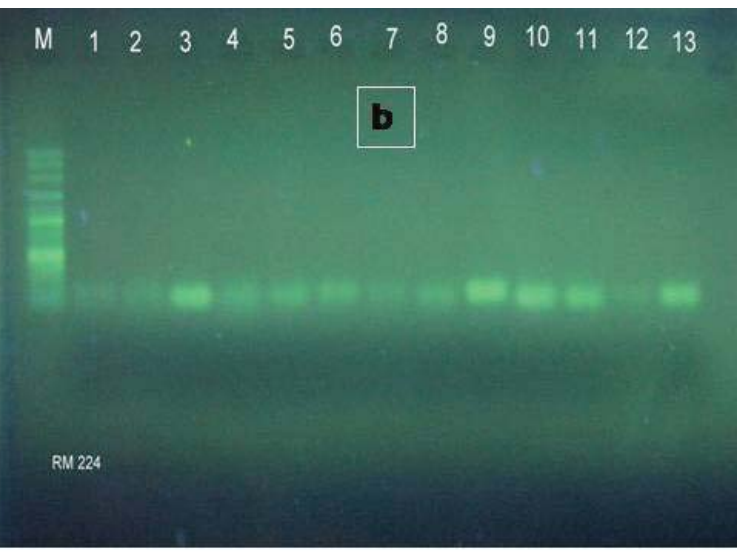

Figure 1. Visualisation of amplification result use RM 224 microsatellite marker on some rice cultivars a. $2 \%$ standard agarose

b. $1 \%$ standard agarose c. $2 \%$ metaphor agarose

$\mathrm{M}=$ Marker $=$ ladder $100 \mathrm{bp}$

1-11 = black rice landraces

12-13 = white rice cultivars 

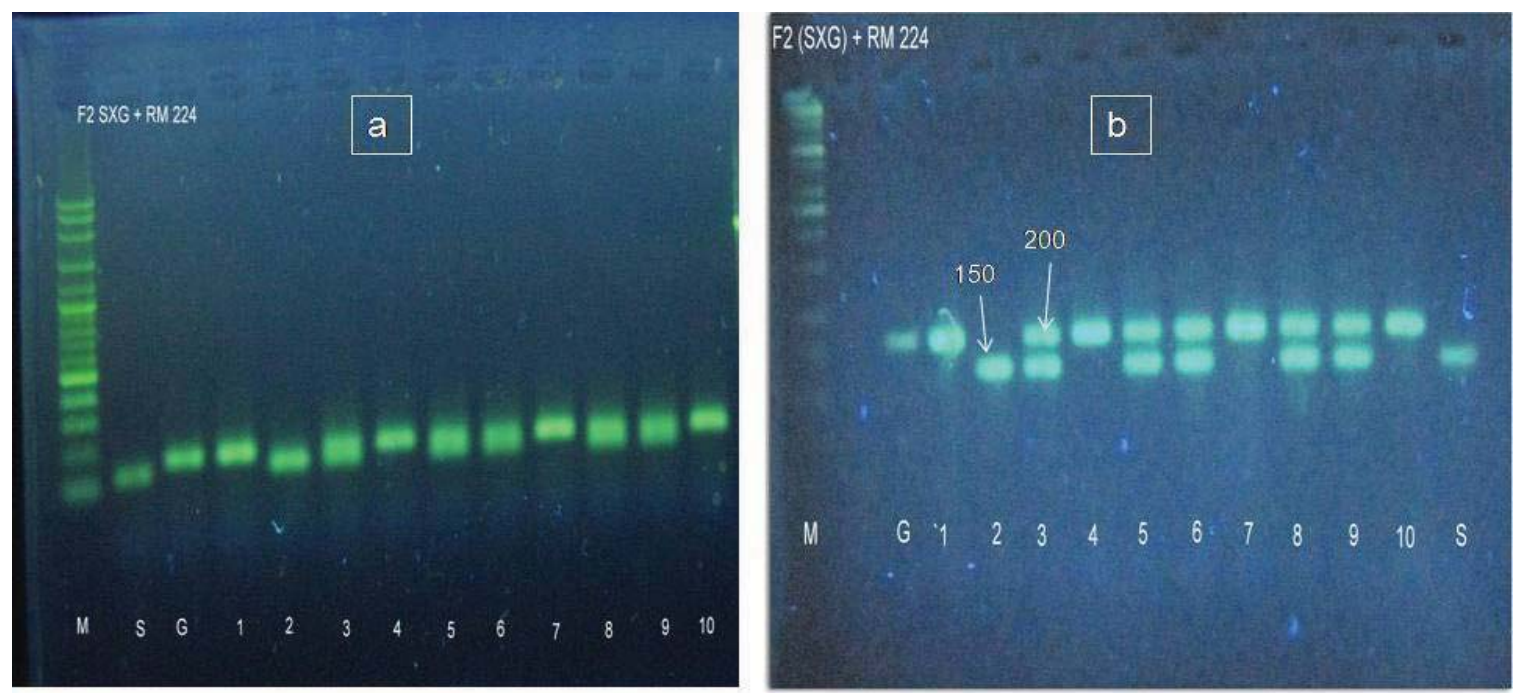

Figure 2. Visualisation of amplification result using RM 224 microsatellite marker on second generation progeny $\left(\mathrm{F}_{2}\right)$ from crosses of black rice of Magelang hairless with Situbagendit white rice. a. $1 \%$ agarose standard; b.

$2 \%$ metaphor agarose

M. Marker $=100 \mathrm{bp}$ ladder

$\mathrm{S}=$ Black rice of Magelang hairless as female parent

$\mathrm{G}=$ Situbagendit white rice as male parent

on some black rice landraces and 2 white rice cultivars after electrophoresis at $80 \mathrm{~V}$ for about 60 minutes. It appeared that MAGE method using $2 \%$ metaphor agarose was clearly able to distinguish two alleles of the RM 224 in the size $125 \mathrm{bp}$ and $150 \mathrm{bp}$ or $25 \mathrm{bp}$ different. Metaphor as also able to differentiate clearly homozygote and heterozygote lines through the production of single and double bands such as column 2 and 3 (figure 1c). These results were not clearly recognized by the use either 1\% (Figure 1a) and 2\% standard agaroses (figure $1 \mathrm{~b}$ ). The use of either $1 \%$ as well as $2 \%$ standard agarose (Figure $1 \mathrm{a} \& 1 \mathrm{~b}$ ) did not show good separation as in Figure 1c using $2 \%$ metaphor agarose.

Figure $2 \mathrm{~b}$ showed that Magelang Hairless (S) and Situbagendit (G) parents were able to be distinguished using RM 224 microsatellite markers after electrophoresis at $80 \mathrm{~V}$ for about 60 minutes. Similar result was visualized by using $1 \%$ standard agarose (figure 2a). The different between standard agarose and metaphor was observed, after they were used to analyze the 10 plants of second generation progeny $\left(\mathrm{F}_{2}\right)$ from crosses of black rice of Magelang hairless with Situbagendit white rice. It revealed that MAGE method using 2\% metaphor agarose clearly distinguished two alleles of the RM 224 at the $150 \mathrm{bp}$ and $200 \mathrm{bp}$ fragment sizes. Column 3, 5, 6, 8 and 9 of figure 2a looked thicker which might be a result of coincide 2 bands. In figure $2 b$, it was clear that the column 3, 5, 6, 8 and 9 produces 2 bands, one band belong to female parent, whereas another band related to male parent so plants at these columns were probably considered as heterozygous lines. In this experiment, metaphor was able to differentiate between homozygous and heterozygous lines as polyacrylamide gel electrophoresis. MAGE was able to visualize the typical characteristics of microsatellite markers as stated by Powell et al. (1996) i.e. codominant nature. Powell et al. (1996) even stated that there were several considerations for the use of microsatellite markers in genetic studies included (1) such markers were abundant and evenly dispersed in the genome, (2) very high diversity due to many alleles within loci, (3) codominant nature, (4) very high 
reproducibility and accuracy; and (5) very accurate for distinguishing the genotype, evaluating seed purity, genetic mapping, and genotyping of desired characteristic, and even studying population genetic and analyzing genetic diversity.

The result of this study indicated that the use of MAGE succeeded in separating the alleles on 25 bp small size different, whereas Asif et al (2008) reported the use of microsatellite markers MGHES MAGE-17 for cotton genome could separate DNA alleles in smaller size that was $5 \mathrm{bp}$. The difference was caused by differences in microsatellite target markers and species.

Polyacrylamide Gel Electrophoresis (PAGE), Metaphor Agarose Gel Electrophoresis (MAGE) and capillary electrophoresis could be used for analysis of microsatellite and all of these methods could provide comparable and reproducible results (Ochsenreither et al., 2006). However, Asif et al. (2008) highlighted that MAGE was more effective, while the use of capillary electrophoresis could be done faster and better, but more expensive and required more sophisticated and expertised technology. Mei et al. (2004); Bolek et al. (2005); and Abdurakhmonov et al. (2007) have used the MAGE method to analyze the microsatellite results on cotton crop with similar result. Therefore, the use of MAGE method to analyze microsatellite results could be the right choice because it was more easy and economics. Asif et al. (2008) said that in order to achieve better resolution, the new microsatellite survey research for screening of parents in plant breeding, the use of fresh metaphor gel was highly recommended. However, subsequent for screening populations with the same microsatellite, metaphor agarose gel could be reused for five to six times, therefore it became more economics.

\section{Conclusion}

Metaphor Agarose Gel Electrophoresis method was effectively and efficiently used to distinguish microsatellite alleles analysis results on the DNA bands with smaller size different which reached less than 25 bp with a high resolution compared to use of agarose at the same concentration.

\section{Daftar Pustaka}

Abdurakhmonov, I.Y., Z.T. Buriev, S. Saha, A.E. Pepper, J.A. Musaev, A. Almatov, S.E. Shermatov, F.N. Kushanov, G.T. Mavlonov, U.K. Reddy, J.Z. Yu, J.N. Jenkins, R.J. Kohel and A. Abdukarimov. 2007. Microsatellite markers associated with lint percentage trait in Cotton, Gossypium hirsutum. Euphytica 156:141156.

Asif, M., M. Rahman and Y. Zafar. 2008. High resolution metaphor agarose gel electrophoresis for genotyping with microsatellite markers. Pakistan Journal of Agricultural Science 45 (1): 75-79.

Azrai, M. 2005. Pemanfaatan marka molekuler dalam proses seleksi pemuliaan tanaman. Jurnal Agrobiogen 1(1) : 2637.

Blair, M.W., O. Panaud, and S.R. McCouch. 1999. Intersimple Squence Repeat (ISSR) amplification for analysis of microsatellite motif frequency and finger-printing in Rice (Oryza sativa L.). Theoretical and Applied Genetics 98:780-792.

Bolek, Y., K.M. El-Zik, A.E. Pepper, A.A. Bell, C.W. Magill, P.M. Thaxton and O.U.K. Reddy. 2005. Mapping of verticillium wilt reistnce genes in cotton. Plant sci. $168: 1581-1590$.

Bucheyeki L.T., C. Gwanama, M. Mgonja, and M. Chisi. 2009. Genetic Variability Characterisation of Tanzania Sorghum Landraces Based on Simple Sequence Repeats (SSRs) Molecular and Morphological Markers. African Crop Science Journal 17: 71 - 86

Cregan, P.B., and C.V. Quigley. 1997. Simple Sequence Repeat DNA marker analysis. p.173-185. In G. Caetano-Anolles and P.M. Gresshoff (ed.) DNA markers: 
Protocols, applications and overviews. John Wiley and Sons, New York.

Doyle J.J and J.L. Doyle. 1990. Isolation of plant DNA from fresh tissue. Focus. Moscow. 12(1):13-15.

Kalestanie, A.R.A, A. Asadi, S.R. Mirfakzarrei, and A.R. Abasi. 2013. Genetic diversity in twenty wheat cultivars using microsatellite markers. International Journal of Agronomy and Plant Production 4: 1920 - 1927

Marino, M.A., L.A. Turni, S.A. Del Rio, P.E. Williams and P.B. Cregan. 1995. The analysis of Simple Sequence Repeat DNA in Soybean by capillary gel electrophoresis. Applied and Theoretical Electrophoresis 5:1-5.

McCouch, S.R. dan S.D. Tanksley. 1991. Development and use of Restriction Fragmenth Length Polimorphism in rice breeding and genetics. In Kush, G.S. and G.H. Toenissen (Eds.). Rice Biotechnology. Biotechnology in Agriculture 8:109-133.

Mei, M., N.H. Syed, W. Gao, P.M. Thaxton, C.W. Smith, D.M. Stelly and Z.J. Chen. 2004. Genetic mapping and QTL analysis of fiber-related Traits in Cotton (Gossypium). Theoretical and Applied Genetics 108:280-291

Pabendon, M.B., E. Regalado, Sutriso, M. Dahlan, dan M.I. George. 2003. Pembentukan klaster genotipe jagung berdasarkan markah SSR (Simple Sequence Repeat). Jurnal Agrobiogen 2(2):45-51.

Pabendon, M.B., M.J. Mejaya, Subandi, dan M. Dahlan. 2005. Sidik jari empat varietas jagung hibrida beserta tetuanya berdasarkan marka mikrosatelit. Zuriat 16 (2) : 192- 201.

Pabendon, M.B., M.J. Mejaya, J. Koswara, dan H. Aswidinnoor. 2007. Analisis Keragaman Genetik Inbrida Jagung Berdasarkan Marka SSR dan Korelasinya dengan Data Fenotipik F1 Hasil Silang Uji. Jurnal Penelitian Pertanian Tanaman Pangan 26 (2) : $69-77$.
Pabendon,M.B., M. Azrai, F. Kasim, dan M.J. Mejaya. 2011. Prospek Penggunaan Markah Molekuler dalam Program Pemuliaan Jagung. http://pustaka. litbang.deptan.go.id/bppi/lengkap/ bpp10236.pdf. Diakses 21 Desember 2011.

Powell, W., G.C. Macharay, and J. Provan. 1996. Polymorphism revealed by Simple Sequence Repeats. Trends in Plant Sci. 1: $215-222$

Senior, M.L., E.C.L. Chin, M. Lee, J.S.C. Smith, and C.W. Stuber. 1996. Simple Sequence Repeat markers developed from maize sequence found in the genebank database; map construction. Crop Science 36: 1676-1683.

Solouki, M.,H., Mehdikhani, H. Zeinali, and A.A. Emamjomeh, 2008. Study of Genetic Diversity in Chamomile (Matricaria chamomilla) based on morphological traits and molecular markers. Sci. Hortic. 117: 281-287.

Susanto, U., Sutrisno dan H. Aswidinnoor. 2009. Pemanfaaan teknlogi markah molekuler untuk perbaikan varietas padi. BBPadi. http:/ / www.litbang. deptan.go.id/special/padi / bbpadi_2009_itkp_13.pdf. 353-365. Diakses 8 Mei 2012.

Utami, D.W., Kristamtini dan Prajitno. 2009. Karakterisasi Plasma Nutfah Padi Beras Merah Lokal Asal Propinsi Daerah Istimewa Yogyakarta Berdasarkan Karakter Morfo-agronomi dan Marka SSRs. Zuriat 20 (1): 10 - 18.

Vigouroux,Y., J.S. Jaqueth, Y. Matsuko, O.S. Smith, W.D. Beavis, J.S.C. Smith and J. Doebley. 2002. Rate and pattern of mutation at microsatellite loci in maize. Molecular Biology Evolution 19 (8): 1251-1260.

White, H.W. and N. Kusukawa. 1997. Agarose-based system for separation of short tandem repeat loci. Biotechnique 22: 976 - 980

Yawadio, R., S. Tanimori and N. Morita. 2007. Identification of phenolic compounds 
Kristamtini et al.

I.J. Biotech.

isolated from pigmented rices and their aldose reductase inhibitory activities. Food Chemistry. 101 (4) : 1616 -1625.

Zhang, P., S. Dreisigacker, A. Buerkert, S. Alkhanjari, A.E. Melchinger, and M.L. Warburton. 2006. Genetic diversity and relationships of wheat landraces from oman investigated with SSR markers. Genetic Resources and Crop Evolution 53: $1351-1360$. 